\title{
unindra
}

Universitas Indraprasta PGRI

Address: Jl. Nangka No. 58 C (TB. Simatupang), Kel. Tanjung Barat, Kec. Jagakarsa, Jakarta Selatan 12530, Indonesia.

+62 (021) 7818718 - 78835283; url: www.unindra.ac.id; 玤psyclrev@unindra.ac.id

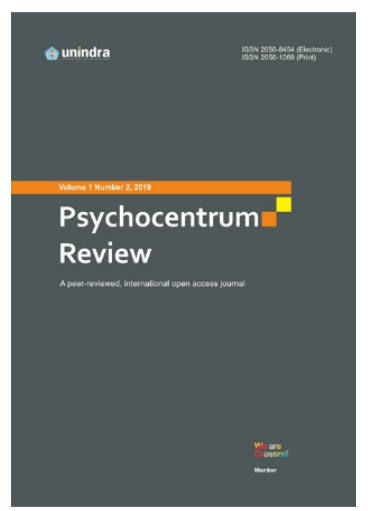

\section{Psychocentrum Review}

ISSN 2656-8454 (Electronic)| ISSN 2656-1069 (Print)

Editor: (D) Yuda Syahputra

Publication details, including author guidelines

URL: http://journal.unindra.ac.id/index.php/pcr/about/submissions\#authorGuidelines

\section{Socio-Demographic Determinants of Money Script Pattern of Undergraduates of University of Lagos}

Sylvester Ororume Atiri ${ }^{1}$, Similoluwa Titilayo Bello²

University of Lagos, Nigeria

\section{Article History}

Received : 29 January 2021

Revised : 15 February 2021

Accepted : 04 March 2021

How to cite this article (APA $6^{\text {th }}$ )

Atiri, S. O., \& Bello, S. T. (2021). Socio-Demographic Determinants of Money Script Pattern of Undergraduates of University of Lagos. Psychocentrum Review, 3(1), 105-118. DOI: 10.26539/pcr.31549

The readers can link to article via https://doi.org/10.26539/pcr.31549

Correspondence regarding this article should be addressed to:

Sylvester Ororume Atiri, Department of Psychology, University of Lagos, Nigeria, E-mail: satiri@unilag.edu.ng

SCROLL DOWN TO READ THIS ARTICLE

Universitas Indraprasta PGRI (as Publisher) makes every effort to ensure the accuracy of all the information (the "Content") contained in the publications. However, we make no representations or warranties whatsoever as to the accuracy, completeness, or suitability for any purpose of the Content. Any opinions and views expressed in this publication are the opinions and views of the authors, and are not the views of or endorsed by Universitas Indraprasta PGRI. The accuracy of the Content should not be relied upon and should be independently verified with primary sources of information.

\section{(c) (1) (3)}

This work is licensed under a Creative Commons Attribution-NonCommercial 4.0 International License.

Copyright by Atiri, S. 0., \& Bello, S. T. (2021)

The authors whose names are listed in this manuscript declared that they have NO affiliations with or involvement in any organization or entity with any financial interes (such as honoraria; educational grants; participation in speakers' bureaus; membership, employment, consultancies, stock ownership, or other equity interest; and exper matter or materials discussed in this manuscript. This statement is signed by all the authors to indicate agreement that the all information in this article is true and correct. 


\title{
Socio-Demographic Determinants of Money Script Pattern of Undergraduates of University of Lagos
}

\author{
$1^{\text {st }}$ Sylvester Ororume Atiri ${ }^{1}, 2^{\text {nd }}$ Similoluwa Titilayo Bello ${ }^{2}$ \\ University of Lagos
}

\begin{abstract}
The study tried to determine the money script pattern of undergraduate students of the university of Lagos, with the aim of examining the influence of sociodemographic factors (that is; sex, age, educational level marital status, current socioeconomic status and childhood socio-economic status) on their money script pattern. The study involved a cross-sectional survey of 385 undergraduates. One standardized psychological instrument; the Klontz-Money Script Inventory (KMSI), was used to elicit data from the participants. The results show that sex had a significant influence on the money script pattern of two out of the four types of money scripts, that is (Money worship script) $\mathrm{F}(1,36)=7.74, \mathrm{P}<.05$ and (Money status script) $\mathrm{F}(1,36)=6.32, \mathrm{P}<.05$. While the other two had no significant influence on the money script pattern of participants, that is, (Money Avoidance script) $\mathrm{F}(1,36)=1.83, \mathrm{P}>.05$ and (Money vigilance script) $\mathrm{F}(1,36)=0.52, \mathrm{P}>.05$. The other socio-demographic factors; marital status, age, educational level current socio-economic status and childhood socioeconomic status did not significantly influence the money script pattern of the participants. The study concluded that the sex of participants to an extent, influences the money script pattern of undergraduates and educational level, marital status, age, current socio-economic and childhood socio-economic status have no influence on the money script pattern of undergraduates.
\end{abstract}

Keywords: Money Script Pattern, Undergraduate Students, Socio-Demographic

Corresponding author: Sylvester Ororume Atiri, Department of Psychology, University of Lagos,Nigeria, E-mail: satiri@unilag.edu.ng

(@) BY.NC This work is licensed under a CC-BY-NC

\section{Introduction}

The term 'money script' was first used by two financial psychologists, namely; Brad Klontz and Ted (Kahler \& Fox, 2005). They defined the term as "a core belief about money that drives financial behaviours."According to Klontz (2009), money script is an "unconscious belief developed in childhood, passed down from generation to generation within families and cultures." Money script is an unconscious core belief an individual holds about money; an individual's behaviour and attitude towards money (Stellar Life Strategies Intl., 2014). According to Klontz and Klontz, (2009), money scripts develop as a result of the experiences in families or cultures. We tend to naturally stick with this beliefs and behaviours about money, it grows in us as we grow up, and if such belief or behaviour is destructive, it might later on lead to abnormal money behaviours Klontz and Klontz, (2009). The disordered money behaviour is dependent on one's belief and attitude towards money (Money scripts). 
Research by Klontz, Brad, Britt, Mentzer, and Klontz (2011) categorised money scripts, as follows: Money Avoidance, Money Status, Money Vigilance, and Money Worship. According to Klontz et. al., Money avoiders (negative attitude towards money), believe that money is not good and it is the source of evil, wealthy individuals are stingy, and they are not worthy of their wealth. Money worshippers (money makes the world go round), such individuals believe in building up their cash reserve (money), they also have the notion that their money can solve all their problems, and this makes them accumulate money as money will never be enough. That is, even when the money they make monthly can cater for all their needs and wants, they still see the need of making more money for the sake of having more money, they feel there is always a void in them that can only be filled when they make or have more money, and anything money can offer. Lastly, they also belief that money brings power and happiness Klontz and Klontz, (2009).

Money status scripts (money is prestige), view their self-worth as proof of their net-worth (what they own), and they attach importance to possessing the most recent and genuine products Klontz and Klontz, (2009). It is such people that are the first to purchase the latest gadgets in the market; they do not wait till the price gets reduced or even purchase discounted products at all, Klontz, \& Klontz, (2009). Money vigilantes' (hoarders), are quick to notice, concious, and are worried concerning their finances. They have a strong feeling against people living on financial handouts, instead of working and take saving very important, such individuals frown at beggars and lazy people. If they cannot pay for something, they will rather forgo it than buy on credit (Klontz, Bradley, and Britt, (2012). This makes, the money vigilant, have a higher net worth and more income. They tend to experience anxiety about their finances and hide their financial standing from people, except their spouses and close family and friends.

Money vigilance results in conservativeness, Goldberg and Lewis (1978), that is, money vigilance makes people engage less in gambling excessively. spending compulsively, do not help people financially (do not readily give out money), while also, ignoring their own finances. This category of money script makes people save their money but may encourage frugality, and makes such individuals not to benefits from the pleasure and security money can bring, Klontz \& Klontz, ( 2009). Three of the four types of money scripts (namely: money worship, money status and money avoidance, ) was reported to be linked with poor financial health, including; smaller income, lower net worth and disordered money behaviour (Klontz, Bradley, \& Britt, 2012). While, money vigilance scripts encourages frugality (being a miser), saving, not being open to discussion about their finances, and are nervous about keeping money in case of future emergency, Goldberg \& Lewis (1978).

The present study was interested in the influence of socio-demographic factors including sex, age, educational level, marital status, current socio-economic status and childhood socioeconomic status has on undergraduate's money script pattern. Age is the chronological years an individual has lived since his/her birth. People's beliefs about money and money scripts develops from childhood and they continue to hold these beliefs in adulthood (Furnham, 1996; Kirkcaldy \& Furnham, 1993). According to Klontz., Britt, Mentzer, and Klontz, (2011) the following; being unmarried, with a low income and net worth, tending to ignore honouring credit card debt fully every month, being young, and being a Caucasian, is associated with money worship script. They also found, similar scores in every age group, for money worship script and money avoidance script. Although, participants that worship money were often in debt, their belief that money makes them happier makes them try to avoid being in debt, (Klontz., et al., 2011).

Tang (1992), found that young people often see money as the origin of evil unlike older people, who often believe their family was poor while growing up and they grew up in families that their parents placed much importance on money compared to younger individuals Furnham, (1984). His finding point to Older participants worrying more about their finances and view their future financial situation negatively Furnham, (1984). 
Sex is the biological distinction between male or female animals, in this case humans. According to Klontz et al. (2011), the sex of an individual is not directly related to the four identified money script patterns. Tang found a not too significant relationship between older individuals and females keeping a budget, and people who are inclined to budgeting and are more satisfied with life. Males have consistently demonstrated to be more obsessed and conservative about money than females, they also belief that money signifies hard work and security (vigilant), Furnham (1984).

Marital status connotes the present status of a human being as being single, married, divorced or separated and being a widow. Klontz et al. (2011), suggested that less educated people, who are younger and single, with lower income, and net worth, more often fall under the category of money avoidance scripts. This is often the case for individuals who worship money too, but money worshippers often indulge in revolving credit (rely on buying and paying later). Money status scripts is more common among younger and single individuals, who are less educated, earn less income, and from a low socio-economic status as children, Klontz, Klontz, \& Britt, (2011). Avoiding credit card debt was common with money vigilance scripts and also, they tend not to owe people money or buy things on credit, Klontz et al. (2011).

The present study, also tried to determine if, people's educational attainment, influences their money script pattern. The early study of Furnham (1984) pointed to educated people being more conservative with money (vigilant). Furnham also found that people with low level of education perceive being poor while growing up unlike those who are more of education. In terms of childhood and current socio-economic status, one may think that beliefs and attitudes towards money is influenced by one's income, but past studies have not established this, (Yamauchi \& Templer, 1982). Although, it appears that there is a little relationship between people who earn higher income feeling money is a measure of accomplishment (money status) and being unlikely to see money as bad (money avoiders), compared with people who earn less income Tang, (1992). Furnham's (1984), Money Belief and Behaviour Scale pointed to a positive correlation between controlling others with money, believing hard work is rewarding financially; and an obsession with money, (money worship). When compared to people's childhood socio-economic status (that is, their family socioeconomic status), people who are classified as money status scripts are most often from lower socio-economic status in childhood, Klontz, Klontz, \& Britt, (2011).

Extent literature from the early study of Roheim, in 1934 on the economic behaviour of indigenous people in Papal New Guinea, concluded that, people's primary motive of having and spending money is symbolic and ceremonial: Money is a symbol of their prestige (Money status), and being wealthy was considered as magical power. Furnham, Stumm, \& FentonO'Creevy (2014), studied the influence sex has on money beliefs and behaviour among 109,472 Britons who completed two on-line questionnaires. Almost all the items had a significant influence on sex with medium to large effect size, The major difference between men and women on the money types is that, money was related to being generous (money representing love) with females scoring much higher than males. In terms of autonomy (money, seen as sign of freedom), men's scores were higher than women. Males, perceived, money as representing Power and Security than females, and tended to be Hoarders while women tended to be involved in emotional and regulatory spending.

Medintz (2004), survey of Americans, concluded that 36\% $(n=1,001)$ avoid thoughts of their financial challenges and money avoidance beliefs was also found to be related to low levels of net worth and income and nonchalant attitude about one's net worth. Furnham's (1984) early research, suggested that, using money to control others, and the belief that hard work is financially rewarding are correlates of income and an obsession with money. He also found that better educated people handle money with caution, while those with less education feel they are from a poorer background than those who attained a higher education than them, Furnham, (1984). 
Tang (1992), studied the money belief amongst 740 participants in the US, and found out that young participants viewed money as being a source of evil more often than older participants. Tang also found that older participants and females keep a budget more than younger and male participants. Participants who keep a budget were also found to report a greater life satisfaction. Furnham, (1984), found that Older people feel they were poor while growing up and raised by parents who were concerned about money than younger people. Older participants also worry more about their finances and view their future financial situations negatively (Furnham). His study also, suggested that males are more obsessed and conservative (that is, old-fashioned), about money than females, and belief money signifies hard work and security. Furnham, pointed to low income earners viewing money as bad or evil than high income earners.

Many studies have been reported worldwide, in the area of money and the attitude people have towards money (money belief and script) (Furnham et al., 2014; Klontz et al., 2011; Medintz, 2004; Kasser \& Sheldon, 2000; Mandel \& Heine, 1999; Roberts, 1998; Tang, 1992; McClure, 1984; Becker, 1975; Roheim, 1934). Only few of this studies, focused on the influence of socio-demographic variables on people's money script pattern. The present study hopes to explore how socio-demographic variables determine people's perception of money. In Western cultures, for example America, people are more individualistic in doing things. They perceive that people's money script patterns somewhat affect how they think and view money in their lives, (Oggins, 2003, Dortch, 1994). Some researchers, such as: (Furnham and his colleagues, 2014; Klontz et al., 2011; Medintz 2004 and Tang, 1992), in their studies pointed to the different social demographic characteristics prone to certain money disorders. For example, they found out that men are likely to be compulsive hoarders (money vigilant), while younger men with high level of income are seen to be workaholics. Individuals that are financially dependent are often unmarried with low level of education and low earnings, who were brought up in wealthy homes (Klontz, Britt, Archuleta, \& Klontz, 2012).

This study laid emphasis on the dynamics socio-demographic variables (sex, age, educational level marital status, current socio-economic status and childhood socio-economic status) has in determining people's money script patterns. As earlier mentioned, only a handful of studies, have been carried out in the area of socio-demographic influence on money script pattern, some of this studies, have pointed to money being a source of disagreement and divorce in relationships Dortch, (1994), beliefs about one's self-worth (Engelberg and Sjöberg, 2007; Hira and Mugenda, 1999; Yamauchi and Templer, 1982 ). A recurring problem of marital discord is finance, Dortch, (1994), but considering that money script patterns are learned in childhood from family and cultural background Klontz and Klontz, (2009), one wonders how spouses are able to change long held patterns of belief about money. According to Furnham, (1996) people continue to hold on to their beliefs about money learned from their childhood, but if learning is an adjustment in behaviour due to new experience Gross, (2012) the money belief individuals hold at a younger age can change when they get older Tang (1992).

If money beliefs or scripts are passed from generation to generation, depending on one's cultural background; Klontz and Klontz (2009) then the bio-data of individuals in terms of their socio-economy, sex and educational attainment might not be significant in determining the belief about money, people hold throughout their lives. Although research has not supported the previous assertions, (Klontz, Britt, Mentzer, \& Klontz, 2011 Furnham (1984). Money issues also agree with Bandura's social learning theory Bandura, (1977). Although, People usually hold onto their childhood perception of money and money scripts in adulthood. (Furnham, 1996; Kirkcaldy \& Furnham, 1993), Bandura's mechanism of learning through modelling Bandura and Walters, (1963), points to people learning through observation of models. This means there is a possibility of change of an individual's previous learning about money (money script) over time Bandura (1971). 
In Nigeria, there is a dearth of studies on money script pattern, but the culture tends towards collectivism, whereby properties like buildings, farms and money are seen to serve a general/collective purpose than for individual purposes (The Hofstede Centre, 2015). The present study is interested in exploring the influence of socio-demographic factors on the money script pattern and beliefs of Nigerians, especially, when one considers the collectivistic culture of most Nigerian cultures. Also, while youths in western cultures are striving to develop in their career, the mind of African youths most often than not is programmed to think, having money by any means would solve their problems Osei-Ajei (2014). The above facts and figures is an indication of the gap in literature in studies on the influence of sociodemographic variables on money script pattern and how socio-demographic variables can contribute to the money belief and money script pattern of Nigerians, hence the present study.

\section{Method}

The study used a cross-sectional survey method. This method enabled the researchers elicit information on the factors that are associated with money script pattern from a sample of undergraduate population. No variable was actively manipulated in the study. The design also made it possible for the researchers to describe the variables of interest as they existed in the population. The dependent variable that was measured is money script pattern, while the independent variables are biodata which includes; sex, age, educational level, childhood socio-economic status, and marital status.

\section{Participants}

The sample for this study, comprised of 385 students of the University of Lagos, who are currently undergoing undergraduate studies at the University. The sampling was drawn using an accidental sampling technique. The sample size used was derived fromwww.raosoft.com, (an online sample calculator), set at an error margin of 5\%,95\%, confidence level with 50\%, response distribution and population size of 10,564, gave a sample size of 385 .

\section{MaterialsandApparatus}

One questionnaire and a standardised psychological scale was used to collect data for the study. The standardised psychological instruments was the Klontz-Money Script Inventory (KMSI). The research protocol was divided into 2 sections. Section A sought sociodemographic data, such as childhood socio-economic status, age, sex, marital status, level of education, and and so on. Section B was an adapted Klontz-Money Script Inventory (KMSI), developed by Klontz, Klontz, and Sonya (2011), was used to elicit information on money script pattern. The instrument is used to identify four types of money belief patterns (that is, avoidance, worship, status, and vigilance money script patterns). It contains 72 money-related beliefs, which participants responded to in a six-point Likert-type response format, ranging from strongly agree, agree, agree a little, disagree, disagree, and strongly disagree. The scale items was developed over a 10 year period of case study evaluation. The items were evaluated via face validity. To find out the category of money script pattern a respondent falls in, points in items $1,5,9,13,17,21,25,29,33,37,42,46,48,30$, and 51 are summed up for Money Avoidance, scores greater than 31 indicate the respondent may exhibit money avoidance beliefs. Points in items 2, 6, 10, 14, 18, 22, 26, 30, 34, 38, and 43 are summed up for Money Worship, scores greater than 23 indicate the respondent may exhibit money worship beliefs. Points in items $3,7,11,15,19,23,27,31,35,40,44,47$, and 49 are summed up for Money Status, scores greater than 27 indicate the respondent may exhibit money status beliefs. While points 
in items $4,8,12,16,20,24,28,32,36,39,41$, and 45 are summed up for Money Vigilance, scores greater than 25 indicate the respondent may exhibit money vigilant beliefs.

\section{Procedures}

Adequate explanation about the study objectives was provided to the participants and those who consented to be part of the study were handed the questionnaires. The questionnaires were administered to respondents in their different faculties individually and retrieved immediately. Each questionnaires was examined and properly sorted to ensure they are properly completed before leaving the presence of the respondents. A total of 440 questionnaires were distributed, 401 were retrieved but only 385 found to be completed without errors were used for data analyses for the study.

\section{DesignorDataAnalysis}

The dependent variable that was measured is money script pattern, while the independent variables are biodata which includes; sex, age, educational level, childhood socio-economic status, and marital status, so the data in this study were analyzed by using MANOVA.

\section{Result}

Guiding Statement of Hypothesis: We hypothesized that: Socio- demographic variables (that is; childhood socio-economic status, age, sex, educational level and marital status) will significantly influence undergraduate student's money script pattern.

The stated hypothesis that; Socio- demographic variables (that is; childhood socioeconomic status, age, sex, educational level and marital status) will significantly influence undergraduate student's money script pattern was tested using MANOVA, and the result shows that:

Sex has a significant influence on two of the money script patterns, while the other sociodemographic characteristics do not significantly influence money script pattern. The MANOVA test conducted to see if age will influence respondents' money script, showed that age did not influence the respondents 'money script. That is, age was not significant to their type of money script. For all the four age groups, age did not affect their money avoidance script $\mathrm{M}=149.54, \mathrm{SD}=9.86$; MANOVA result shows no significant different in scores $\mathrm{F}(3,355)=1.58, \mathrm{P}>.05$ (not significant). For Money worship script $\mathrm{M}=22.95, \mathrm{SD}=8.78$; MANOVA result shows no significant different in scores $\mathrm{F}(3,36)=0.30, \mathrm{P}>.05$ (not significant). For Money status script $\mathrm{M}=58.88, \mathrm{SD}=8.63$; MANOVA result shows no significant different in scores $\mathrm{F}(3,36)=0.81, \mathrm{P}>.05$ (not significant). For Money vigilance script $\mathrm{M}=22.31, \mathrm{SD}=7.99$; ANOVA result shows no significant different in scores $\mathrm{F}(3,36)$ $=0.34, \mathrm{P}>.05$ (not significant).

For sex, the MANOVA result showed that two of the four types of money scripts were influenced by sex while the other two were not. Money Avoidance script $\mathrm{M}=173.72, \mathrm{SD}=$ 9.86; MANOVA result shows no significant different in scores $\mathrm{F}(1,357)=1.83, \mathrm{P}>.05$ (not significant). Money worship script $\mathrm{M}=589.65, \mathrm{SD}=8.78$; MANOVA result shows a significant different in scores $\mathrm{F}(1,36)=7.74, \mathrm{P}<.05$ (significant). For Money status script $\mathrm{M}=$ 460.94, $\mathrm{SD}=8.63$; MANOVA result shows a significant difference in scores $\mathrm{F}(1,357)=6.32$, $\mathrm{P}<.05$ (significant). For Money vigilance script $\mathrm{M}=33.56, \mathrm{SD}=8.07$; MANOVA result shows no significant difference in scores $\mathrm{F}(1,36)=0.52, \mathrm{P}>.05$ (not significant). 
Table 1. MANOVA summary table showing the level of significance between the socio-demographic characteristics and the four types of money scripts.

\begin{tabular}{|c|c|c|c|c|c|c|c|}
\hline Source & Dependent Variable & $\begin{array}{l}\text { Type III } \\
\text { Sum } \\
\text { Squares }\end{array}$ & of & $\begin{array}{l}\text { D } \\
\text { f }\end{array}$ & $\begin{array}{l}\text { Mean } \\
\text { Square }\end{array}$ & $\mathbf{F}$ & Sig. \\
\hline \multirow[t]{7}{*}{ SEX } & MONEYAVOIDANC & 173.72 & & 1 & 173.72 & $\begin{array}{l}1.8 \\
3\end{array}$ & $\begin{array}{l}0.1 \\
8\end{array}$ \\
\hline & MONEYWORSHIP & 589.65 & & 1 & 589.65 & 7.7 & 0.0 \\
\hline & & & & & & 4 & 1 \\
\hline & MONEYSTATUS & 460.94 & & 1 & 460.94 & 6.3 & 0.0 \\
\hline & & & & & & 2 & 1 \\
\hline & MONEYVIGILANCE & 33.56 & & 1 & 33.56 & 0.5 & 0.4 \\
\hline & & & & & & 2 & 7 \\
\hline \multirow[t]{8}{*}{ AGE } & MONEYAVOIDANC & 448.61 & & 3 & 149.54 & 1.5 & 0.2 \\
\hline & $\mathrm{E}$ & & & & & 8 & 0 \\
\hline & MONEYWORSHIP & 68.86 & & 3 & 22.95 & 0.3 & 0.8 \\
\hline & & & & & & 0 & 3 \\
\hline & MONEYSTATUS & 176.65 & & 3 & 58.88 & 0.8 & 0.4 \\
\hline & & & & & & 1 & 9 \\
\hline & MONEYVIGILANCE & 66.94 & & 3 & 22.31 & 0.3 & 0.8 \\
\hline & & & & & & 4 & 0 \\
\hline \multirow[t]{8}{*}{ MARITAL STATUS } & MONEYAVOIDANC & 607.27 & & 3 & 202.43 & 2.1 & 0.1 \\
\hline & & & & & & 3 & 0 \\
\hline & MONEYWORSHIP & 292.72 & & 3 & 97.57 & 1.2 & 0.2 \\
\hline & & & & & & 8 & 8 \\
\hline & MONEYSTATUS & 421.97 & & 3 & 140.66 & 1.9 & 0.1 \\
\hline & & & & & & 3 & 3 \\
\hline & MONEYVIGILANCE & 348.26 & & 3 & 116.09 & 1.7 & 0.1 \\
\hline & & & & & & 8 & 5 \\
\hline \multirow{8}{*}{$\begin{array}{l}\text { EDUCATIONLEVE } \\
\text { L }\end{array}$} & MONEYAVOIDANC & 700.57 & & 3 & 233.52 & 2.4 & 0.0 \\
\hline & E & & & & & 6 & 6 \\
\hline & MONEYWORSHIP & 170.90 & & 3 & 56.97 & 0.7 & 0.5 \\
\hline & & & & & & 5 & 2 \\
\hline & MONEYSTATUS & 552.29 & & 3 & 184.10 & 2.5 & 0.0 \\
\hline & & & & & & 2 & 6 \\
\hline & MONEYVIGILANCE & 198.44 & & 3 & 66.15 & 1.0 & 0.3 \\
\hline & & & & & & 1 & 9 \\
\hline \multirow[t]{8}{*}{ CURRENTSES } & MONEYAVOIDANC & 295.18 & & 2 & 147.59 & 1.5 & 0.2 \\
\hline & $\mathrm{E}$ & & & & & 6 & 1 \\
\hline & MONEYWORSHIP & 178.51 & & 2 & 89.26 & 1.1 & 0.3 \\
\hline & & & & & & 7 & 1 \\
\hline & MONEYSTATUS & 195.28 & & 2 & 97.64 & 1.3 & 0.2 \\
\hline & & & & & & 4 & 6 \\
\hline & MONEYVIGILANCE & 200.58 & & 2 & 100.29 & 1.5 & 0.2 \\
\hline & & & & & & 4 & 2 \\
\hline \multirow[t]{6}{*}{ CHILDHOODSES } & MONEYAVOIDANC & 112.31 & & 2 & 56.15 & 0.5 & 0.5 \\
\hline & & & & & & 9 & 5 \\
\hline & MONEYWORSHIP & 66.59 & & 2 & 33.29 & 0.4 & 0.6 \\
\hline & & & & & & 4 & 5 \\
\hline & MONEYSTATUS & 70.62 & & 2 & 35.31 & 0.4 & 0.6 \\
\hline & & & & & & 8 & 2 \\
\hline
\end{tabular}


For Education level, the MANOVA result showed participant's level of education does not influence the four types of money scripts. For Money Avoidance script $\mathrm{M}=233.52, \mathrm{SD}=9.86$; MANOVA result shows no significant difference in scores $F(3,36)=2.46, \mathrm{P}>.05$ (not significant). Money worship script $\mathrm{M}=56.97, \mathrm{SD}=8.78$; MANOVA result shows no significant difference in scores $\mathrm{F}(3,36)=0.75, \mathrm{P}<.05$ (not significant). For Money status script $\mathrm{M}=184.10, \mathrm{SD}=8.63$; MANOVA result shows no significant difference in scores $\mathrm{F}$ $(3,36)=2.53, \mathrm{P}<.05$ (not significant). For Money vigilance script $\mathrm{M}=66.15, \mathrm{SD}=8.07$; MANOVA result shows no significant difference in scores $F(3,355)=1.01, P>.05$ (not significant).

From the MANOVA conducted to see if marital status will influence respondents' money script, all the respondents in the four classified marital categories were not influenced by their marital status. For all the four classified marital categories, marital status did not affect their money avoidance script $\mathrm{M}=202.43, \mathrm{SD}=9.86$; MANOVA result shows no significant different in scores $\mathrm{F}(3,36)=2.13, \mathrm{P}>.05$ (not significant). For Money worship script $\mathrm{M}=$ 97.57, $\mathrm{SD}=8.78$; MANOVA result shows no significant difference in scores $\mathrm{F}(3,36)=1.28$, $\mathrm{P}>.05$ (not significant). For Money status script $\mathrm{M}=140.66, \mathrm{SD}=8.63$; MANOVA result shows no significant difference in scores $\mathrm{F}(3,36)=1.93, \mathrm{P}>.05$ (not significant). For Money vigilance script $\mathrm{M}=116.09, \mathrm{SD}=8.07$; MANOVA result shows no significant difference in scores $\mathrm{F}(3,36)=1.78, \mathrm{P}>.05$ (not significant).

From the analysis to check if current social economic status will influence respondents' money script pattern, all the respondents in the three classified social economic categories were not influenced by their current social economic status. The three classified socio economic categories, did not influence their money avoidance script $\mathrm{M}=147.59, \mathrm{SD}=9.86$; MANOVA result shows no significant difference in scores $F(2,36)=1.56, \mathrm{P}>.05$ (not significant). For Money worship script $\mathrm{M}=89.26, \mathrm{SD}=8.78$; MANOVA result shows no significant difference in scores $\mathrm{F}(2,356)=1.17, \mathrm{P}>.05$ (not significant). For Money status script $\mathrm{M}=97.64, \mathrm{SD}=8.64$; MANOVA result shows no significant difference in scores $\mathrm{F}$ $(2,356)=1.34, \mathrm{P}>.05$ (not significant). For Money vigilance script $\mathrm{M}=100.29, \mathrm{SD}=8.07$; MANOVA result shows no significant difference in scores $F(2,36)=1.54, \mathrm{P}>.05$ (not significant).

The result of the one way MANOVA on the influence of childhood social economic status on respondent's money script pattern, shows that, all the respondents in the three classified social economic categories were not influenced by their childhood social economic status. For all the three classified socio economic categories, their childhood socio-economic status had no influence on their money avoidance script $\mathrm{M}=56.15, \mathrm{SD}=9.86$; MANOVA result shows no significant difference in scores $\mathrm{F}(2,36)=0.59, \mathrm{P}>.05$ (not significant). For Money worship script $\mathrm{M}=33.29, \mathrm{SD}=8.78$; MANOVA result shows no significant difference in scores $\mathrm{F}$ $(2,36)=0.44, \mathrm{P}>.05$ (not significant). For Money status script $\mathrm{M}=35.31$, $\mathrm{SD}=8.63$; MANOVA result shows no significant different in scores $\mathrm{F}(2,36)=0.48, \mathrm{P}>.05$ (not significant). For Money vigilance script $\mathrm{M}=2.87, \mathrm{SD}=8.07$; MANOVA result shows no significant difference in scores $\mathrm{F}(2,36)=0.04, \mathrm{P}>.05$ (not significant).

The result of this hypothesis is mixed, while there is evidence in support of the hypothesis, that there is no significant influence of Age, marital status, education level, current socioeconomic status and childhood socio-economic status. In respect to sex, and its influence on money script pattern, our result shows that sex had a significant influence on the money script pattern of two out of the four types of money scripts, that is (Money worship script and Money status script). While it (sex) had no significant influence on the other two (Money Avoidance and Money vigilance script) money script pattern of participants. Thus, hypothesis which 
states that 'socio demographic variables will significantly influence undergraduate's money script pattern, was not wholly accepted or rejected.

\section{Discussion}

The present study examined the socio-demographic determinants of money script patterns, among university of Lagos students with the aim of determining the influence of socio-demographic variables on the money script pattern of university students. The finding of this study revealed interesting outcomes. The result of the present study shows that while sex to an extent influenced the money script pattern of participants, the other biodata factors (age, marital status, level of education, current socio-economic status and childhood socioeconomic status) had no influence on the money script pattern of participants. A break down of this result shows that sex had an influence on the money script pattern of two out of the four types of money scripts patterns, that is (Money worship script and Money status script). While the other two (Money Avoidance script and Money vigilance script) had no influence on the money script pattern of participants. The findings of the present study, further showed that, female students held money worship and money status beliefs more than male participants, male participants tend to be more of money vigilance and tilted towards money status in their beliefs about money. Our result is in consonant with that of Lynn, (1991) whose result suggested that men usually use money for competition and to define who they are, (money status syndrome).

The result of the present study is not in agreement with Newcom and Rabow (1999), their result showed that. men believe money improves their self-esteem, feeling of happiness and control. This also makes them view money positively. This finding translates that men have a money worship belief. The difference in their findings, and our study, maybe, due to a gap in time between their study in 1999 and the present study conducted in 2020. Another reason for the difference in the findings of the two studies is the difference in sample, the present study involved participants drawn from a sample of university undergraduates while that of Newcom and Rabow (1999) consisted of adults who were employed.

The present study also found that the age of participants did not significantly influence the money script pattern of participants, across the age categories of those involved in the study. Our finding is not in consonant with Tang (1992), that pointed to younger people tending towards money avoiders. This difference, in Tang's (1992) study from the present study, may have been due to the different instruments both studies used for their measurement. Tang measured money belief with the Money Ethic Scale (MES) that he developed himself Tang (1992), while this study relied on Klontz-Money Script Inventory (KMSI). Also, Tang's study was carried out two decades ago. Tang (1992), while this study was undertaken in 2020. Another reason that may have caused a difference, is that, Tang used a sample that consisted of employed adults while the present study involved a sample of undergraduates. Gautam \& Matta (2016), also reported that age is a significant socio-demographic factor that determined financial behaviour (Furnham, 1984). Older participants often experience anxiety over their finances and are less positive about their future financial situation (Furnham).

The result of our study, also shows that, participant's level of education does not influence their money script pattern. This finding is not in agreement with Furnham's (1984), that showed a positive correlation between participant's level of education and money belief. His finding showed that education as an influence on people's money beliefs. Furnham suggested that educated people have a more conservative outlook towards money. Furnham also reported that participants who are less educated feel that those with higher level of education were better off than them during their childhood.

The finding of the present study further show, that, participant's current and childhood socio-economic status had no influence on their self-reported money script pattern. This result 
contradicts that of Tang, (1992) Who found a slight correlation between childhood socioeconomic status and money belief as persons with higher socio-economic status in childhood, feel that money signifies of success (money status) and unlikely to perceive money as bad compared to those from low socio-economic status during childhood (Tang, 1992). Furnham (1984) also reported that the is a relationship between people's money belief and their income. He reported that those with higher income use money to control others, for power, are obsessed with money and they feel that hard work leads to financial reward (money as status). The difference in the finding of the present study from Tang (1992) and Furnham (1984), can be due to the measures used to assess money belief. While the present study used an adapted Klontz-Money Script Inventory (KMSI), developed by Klontz, Klontz, and Sonya ( 2011), Tang ansd Furnham used their Money Ethic Scale (MES)Tang (1992), and Money Belief and Behaviour Scale(MBS) Furnmam (1984) respectively. The differences in the years the present study was carried out and theirs might have also caused a difference in the findings.

Though, it is easy to assume that beliefs and attitude about money can be influenced by people's earning, past studies has not confirmed this connection, (Yamauchi \& Templer, 1982). Early on Yamauchi and Templer (1982), found that people's belief and attitude about money, point to money being a symbol of achievement or "status." They also suggested a feeling of being anxious is experienced by people regarding money; for a few, money helped their level of anxiety while for others it resulted anxiety. 'More recent studies, point to people who feel that money is a symbol of status being more anxious than the general population about their finances because of their perception that their social status would be affected by lower levels of wealth" (Engelberg \& Sjöberg, 2007).

Feeling of self-worth was found to be positively influenced by a person's financial satisfaction and one's interpretation of the present, the future and past financial situation (money status), and negatively influenced by financial worry and overspending (Hira \& Mugenda, 1999).

Finally the present study did not find a correlation between childhood money belief and later life money script pattern. Our study is not in line with the study by of Klontz, Britt, Mentzer,and Klontz, (2011), who found that children raised in homes with lower socioeconomic status, are likely to be inclined to the money status beliefs. Although, Britt, Mentzer,and Klontz, (2011), used the same instrument with the present study to measure money belief, the Klontz-Money Script Inventory (KMSI), the finding of the present study and that of Britt,Mentzer,and Klontz, (2011), may not be in consonant, because of the difference in sample. While the present study used university students as participants Klontz, Britt, Mentzer,and Klontz, (2011), used a sample of employed adults. Also the difference in the time in terms of the year the previous study 2011 was carried out and the present study, carried out 2020 can also result in the difference in findings.

Like the social learning theory of Bandura, (1977), that point to learning by observation, people are likely to continue to hold onto their feeling concerning money and money skills learned when they were children in their later lives (Furnham, 1996; Kirkcaldy \& Furnham, 1993). Regrettably, such money skills and attitude may become canter productive if parents or guardians held an unhealthy perception about money. Klontz and Klontz (2009). The social learning theory of Bandura (1977) goes further to posit that, people learn behaviour through modelling. Individuals can copy the people they see as models, and therefore belief that the behaviour of these models are appropriate Bandura (1977).

\section{Conclusion}

The present study demonstrates that sex. being male or female influenced participant's money script pattern. While the other socio-demographic variables; childhood socio- 
economic status, age, current socio-economic status and marital status, have no influence on money script pattern of participant's.

\section{Acknowledgements}

It is recommended that further studies should involve participants that are financially independent, as this would provide more insight on the influence socio-demographic factors might have on the money script pattern of people, since they are in control of their finances unlike the student population involved in this study.

Others socio-demographic variables like years of experience, family background, religion and religiosity should be considered to check their influence on the money script pattern that people hold.

\section{References}

Anderson, M. A., Gillig, P. M., Sitaker, M., McCloskey, K., Malloy, K., \& Grigsby, N. (2003). Why doesn't she just leave? A descriptive study of victim reported impediments to her safety. Journal of Family Violence, 18(3), 151-155.

American Psychiatric Association. (2000). Diagnostic Statistical Manual of mental disorders$I V$-TR (4th ed.). Washington, DC: Author.

American Psychological Association. (2015). Education and socioeconomic status. Retrieved from http://www.apa.org/pi/ses/resources/publications/factsheet-education.aspx

Aquilino, W., \& Supple, A. (2001). Long term effects of parenting practices during adolescence on well-being outcomes in young adulthood. Journal of Family Issues, 22, 289-308

Akinsola \& A. Fagbohungbe (Eds.), Learning (pp. 143). Lagos, Nigeria: Department of Psychology, University of Lagos

Ayenibiowo, K.O. (2009). Psychological foundations. In K. Ogutuashe, G.A. Sote, E.F.

Bandura, A. (1977). Social learning theory. New York: General Learning Press.

Becker, E. (1975). Escape from evil. New York, NY: The Free Press.

Boundless. (2014). Drive-reduction theory. Retrieved 2015, April, 23 from https://www.boundless.com/psychology/textbooks/boundless-psychologytextbook/motivation-12/approaches-to-explaining-motivation-65/drive-reductiontheory-250-12785/

Chen, T. (2015). American household credit card statistics. Retrieved from http://www.nerdwallet.com/blog/credit-card-data/average-credit-debt-household/

Diener, E., \& Biswas-Diener, R. (2008). Happiness: Unlocking the mysteries of psychological wealth. New York, NY: Wiley-Blackwell.

Dittmar, H. (2010). Consumer culture, identity and well-being: The search for the 'good life' and the 'body perfect'. New York, NY: Psychology Press.

Dortch, S. (1994). Money and marital disorder. American Demographics, 16, 11-14.

Engelberg, E., \& Sjöberg, L. (2006). Money attitudes and emotional intelligence. Journal of Applied Social Psychology, 36(8), 2027-2047.

Engelberg, E., \& Sjöberg, L. (2007). Money obsession, social adjustment, and economic risk perception. Journal of Socio-Economics, 36(5), 686-697.

Faber, R. J., \& O'Guinn, T. C. (1992). A clinical screener for compulsive buying. The Journal of Consumer Research, 19(3), 459-469.

Forman, N. (1987). Mind over money. Toronto: Doubleday.

Fromm, E. (1976). To have or to be? New York, NY: Harper and Row. 
Furnham, A. (1984). Money sides of the coin: The psychology of money usage. Personality and Individual Difference, 5(5), 501-509.

Furnham, A. (1996). Attitudinal correlates and demographic predictors of monetary beliefs and behaviours. Journal of Organizational Behaviour, 17(4), 375-388.

Furnham, A., Stumm, S.V., \& Fenton-O'Creevy, M. (2015). Sex differences in money pathology in the general population. Social Indicators Research, 123(3), 701-711.

Gallen, R. (2002). The money trap: A practical program to stop self-defeating financial habits so you can reclaim your grip on life. New York: Harper Collins Publishers.

Gerson, E. S., \& Woolsey, B. (2009). The history of credit cards. Retrieved from http://www.creditcards.com/credit-card-news/credit-cards-history-1264.php.

Goldberg, H., \& Lewis, R. T. (1978). Money madness: The psychology of saving, spending, loving, and hating money. New York: William Morrow and Company, Inc.

Hanley, A., \& Wilhelm, M. S. (1992). Compulsive buying: An exploration into self-esteem and money attitudes. Journal of Economic Psychology, 13, 5-18.

Hira, T.K., \& Mugenda, O.M. (1999). The relationships between self-worth and financial beliefs, behaviour, and satisfaction. Journal of Family and Consumer Sciences, 91(4), 76-82.

Hirschman, E. C. (1990). Secular immortality and the American ideology of affluence. Journal of Consumer Research, 17, 31-42.

Kahler, Rick, \& Kathleen, F. (2005). Conscious finance: Uncover your hidden beliefs and transform the role of money in your life. South Dakota: FoxCraft Inc.

Kasser, T., \& Sheldon, K. M. (2000). Of wealth and death: Materialism, mortality salience, and consumption behaviour. Psychological Science, 11, 348-351. http://dx.doi.org/10.1111/1467-9280.00269.

Kasser, T. (2003). The high price of materialism. Cambridge, MA: The MIT Press.

Kasser, T., Ryan, R. M., Couchman, C. E., \& Sheldon, K. M. (2004). Materialistic values: Their causes and consequences. In T. Kasser \& A. D. Kanner (Eds.), Psychology and consumer culture (pp. 11-28). Washington, DC: American Psychological Association.

Kirkcaldy, B., \& Furnham, A. (1993). Predictors of beliefs about money. Psychological Reports, 73(3), 1079-1082.

Klontz, Brad, T. \& Klontz, T. (2009). Mind over money: Overcoming the money disorders that threaten our financial health. New York: Broadway Business

Klontz, \& Brad, T. (2011). Behaviour modification: Clients may need your help discovering the childhood beliefs affecting their financial decisions today. Journal ofFinancial Planning, (April).

Klontz, Brad, T., Britt, S.L., Mentzer, J., \& Klontz, T. (2011). Money beliefs and financial behaviours: Development of the Klontz money script inventory. Journal of Financial Therapy 2, 1: 1-22

Klontz, B. T., Britt, S. L., Archuleta, K. L., and Klontz, T. (2012). Disordered money behaviours: Development of the Klontz money behaviour inventory. Journal of Financial Therapy: Vol. 3: Iss. 1, Article 2. http://dx.doi.org/10.4148/jft.v3i1.1485

Klontz, B., Britt, S., Archuleta, K., \& Klontz, T. (2012). Disordered money behaviours. Journal of Financial Therapy, 3, 17-43.

Klontz, B., Bradley, T., Britt, S. L. (2012). How clients' money scripts predict their financial behaviours. Journal of Financial Planning, 25 (11), 4 - 11.

Lynn, R. (1991a). Sex differences in competitiveness and the valuation of money in twenty countries. Journal of Psychology, 133, 507-511.

Mandel, N., \& Heine, S. (1999). Terror management and marketing: He who dies with the most toys wins. In E. J. Arnould \& L. M. Scott (Eds.). Advances in consumer research (Vol. 26, pp. 527-532). Provo, UT: Association for Consumer Research.

Maslow, A. H. (1954). Motivation and personality. New York, NY: Harper and Row. 
McClure, R. F. (1984). The relationship between money attitudes and overall pathology, Psychology. A Quarterly Journal of Human Behaviour, 21 (1), 4-6.

McLeod, S.A. (2007). Maslow's Hierarchy of needs. Retrieved from http://www.simplypsychology.org/maslow.html

Medintz, S. (2004). Secrets, lies and money. Money, 34(4), 121-128.

Mumford, D., \& Weeks, G. (2003). The money genogram. Journal of Family Psychotherapy, $14,33-45$.

Neuman, F. (2013). Changing gender roles in marriage. Retrieved 2015, October, 13 from http://www.psychologytoday.com/blog/fighting-fear/201301/changing-gender-rolesin-marriage

Newcomb, M. D., \& Rabow, J. (1999). Gender, socialization and money. Journal of Applied Social Psychology, 29(4), 852-869.

Ng, T., Sorenson, K., \& Feldman, D. (2007). Dimensions, antecedents, and consequences of workaholism: A conceptual integration and extension. Journal of Organizational Behaviour, 28, 111-136.

Oggins, J. (2003). Topics of marital disagreement among African-American and EuroAmerican newlyweds. Psychological Reports, 92, 419-425.

Osei-Ajei, P. (2014). The mind-set of money and money has completely detached the intelligence of Africans. Retrieved 2016, May, 16 from http://www.opinionnigeria.com/the-mindset-of-money-and-money-has-completelydetached-the-intelligence-of-africans/\#.dpuf

Oxford Dictionaries. (2015). Definition of money in English. Retrieved 2015, March from http://www.oxforddictionaries.com/definition/english/money

Pearce, S. M. (1992). Museums, objects, and collections: A cultural study. Leicester: Leicester University Press.

Petry, N. M. (2005). Pathological gambling: Etiology comorbidity, and treatment. Washington, D.C.: American Psychological Association.

Richard Gross, Psychology: The Science of Mind and Behaviour 6E, Hachette UK, ISBN9781-4441-6436-7.

Robert, J.A. (1998). Compulsive buying among college students: An investigation of it antecedents, consequences, and implications for public policy. The Journal of Consumer Affair, 32 (2), 295 - 319.

Robinson, B. E., \& Kelley, L. (1998). Adult children of workaholics: Self-concept, anxiety, depression, and locus of control. The American Journal of Family Therapy, 26, 223238.

Rohling, M. L., Binder, L. M., \& Langhinrichsen-Rohling, J. (1995). A meta-analytic review of the association between financial compensation and the experience and treatment of chronic pain. Health Psychology, 14, 537-547.

Rubenstein, C. (1981). Money and self-esteem, relationships, secrecy, envy, satisfaction. Psychology Today, 15 (5), 29-44.

Schneider, J. (2000). The increasing financial dependency of young people on their parents. Journal of Youth Studies, 3(1), 5-20.

Sincerp, S.M., (2012). Incentive theory of motivation. Retrieved 2015, Apr 30 from Explorable.com:https:/explorable.com/incentive-theory-of-motivation

Spence, J. T., \& Robbins, A. S. (1992). Workaholism: Definition and preliminary results. Journal of Personality Assessment, 58(1), 160-178.

Stellar Life Strategies Intl. (2014, March 6). Got money stress? Retrieved from:http://www.stellarlifestrtegies.com

Tang, T. L. (1992). The meaning of money revisited. Journal of Organizational Behaviour, 13(2), 197-202.

Thaler, R., \& Sunstein, C. (2008). Nudge: Improving decisions about health, wealth, and happiness. New Haven: Yale University Press. 
The Hofstede Centre. (2015). The culture factor. Retrieved from http://geerthofstede.com/nigeria.html

The Mother Service Society. (2015). Social and psychological value of money. Retrieved from http://www.mssresearch.org.

Tolin, D., Frost, R., \& Steketee, G. (2007). Buried in treasures: Help for compulsive acquiring, saving and hoarding. Oxford, England: Oxford University Press.

World Health Organisation. (2015). Gender, equity and human rights. Retrieved from http://www.who.int/gender-equity-rights/understanding/gender-defintion/en/

Yamauchi, K. T., \& Templer, D. J. (1982). The development of a money attitude scale. Journal of Personality Assessment, 46(5), 522-528.

Yalom, I. D. (1980). Existential psychotherapy. New York, NY: Basic Books.

Yip, P. (2013, June 15). Psychological money script can shape financial life. The Seattle Time. Retrieved from http://www.seattletimes.com/business/psychological-Isquomoneyscriptrsquo-can-shape-financial-life 